\title{
Nabuco e Alencar
}

Eduardo Vieira Martins

Universidade de São Paulo

Resumo: Oobjetivo deste artigo é analisar as ideias desenvolvidas por Joaquim Nabuco e José de Alencar na polêmica travada em 1875, especialmente suas consideraçōes sobre dois gêneros, o romance e o teatro.

Palavras-chave: romance, teatro, polêmica literária.

Quando se enfrentaram na polêmica travada nas páginas de $O$ Globo, em 1875, Joaquim Nabuco e José de Alencar se encontravam em posições e momentos opostos no que diz respeito a suas vidas particulares e a suas carreiras profissionais. O jovem Nabuco, filho do eminente senador José Tomás Nabuco de Araújo, chegara havia um ano de uma viagem à Europa e procurava, um pouco a esmo, iniciar uma carreira na corte, buscando alternativas à política, na qual seu pai insistia que ele ingressasse. Anos depois, ao recordar essa fase de sua vida, observou que a experiência europeia havia arrefecido seu interesse pelas disputas partidárias, dando asas às veleidades literárias: "Como se vê, bem pouco do político dominante restava depois dessa primeira viagem à Europa; eu trocara em Paris e na Itália a ambição política pela literária: voltava cheio de ideias de poesia, arte, história, 
literatura, crítica, isto é, com uma espessa camada europeia na imaginação, camada impermeável à política local [...]”. . Com esse espírito, de volta ao Rio de Janeiro, fez palestras sobre arte, procurando apresentar o que tinha visto e aprendido no Velho Mundo, e, a seguir, começou a escrever textos de crítica n'O Globo. ${ }^{2}$

O velho conselheiro Alencar, que iniciara sua carreira literária em 1856-57, com a polêmica sobre $A$ confederação dos Tamoios e a publicação de seus primeiros romances, Cinco minutos e $O$ guarani, havia se firmado no correr dos anos como um dos mais importantes escritores do país, sendo visto por muitos admiradores como o "chefe da literatura brasileira". Simultaneamente à atividade literária, desempenhava as funções de advogado, jornalista e político; era deputado pelo partido conservador e, por um breve período, foi ministro da justiça do gabinete ultraconservador capitaneado por Itaboraí. Contudo, desde o começo da década de 1870, a posição de destaque que ele logrou atingir mostrou o seu reverso e Alencar tornou-se alvo de questionamentos nos campos político e literário: no primeiro, teve sua candidatura ao senado barrada por Dom Pedro II e, em 1871, foi duramente atacado por se colocar contra a lei do ventre livre; no segundo, sua obra era criticada por escritores da nova geração, que, a exemplo de Franklin Távora, autor das Cartas a Cincinato (1871-72), arguiam o que lhes parecia excesso de imaginação e descuido na observação das paisagens e tipos humanos representados em seus romances. O próprio Alencar, sentindo a mudança dos ventos, que começavam a bater contra ele, assinou O gaúcho, publicado em 1870, com o pseudônimo de Sênio, justificando a escolha com o argumento de que havia se tornado "um anacronismo literário".

As vidas de Alencar e Nabuco se cruzam em setembro de 1875, opondo, de um lado, um homem abatido pela tuberculose, que se sentia prematuramente envelhecido e que via suas concepções políticas e estéticas sendo paulatinamente postas de lado num mundo em rápida transformação, onde tudo parecia estar ruindo; e, de outro, um jovem recém-chegado da Europa, informado sobre as novidades dos centros irradiadores de cultura, que voltava para casa sedento

1. NABUCO. Minha formação, p. 71 .

2. Segundo Brito Broca, "depois de Machado, Nabuco [foi] o primeiro a fazer crítica literária no rigor da palavra entre nós [...]”. Ver BROCA. Românticos, pré-românticos, ultra-românticos, p. 319. Sobre o percurso de Nabuco, ver ALONSO. Joaquim Nabuco.

3. ALENCAR. O gaúcho. O tronco do ipê, p. 2. 
por se afirmar e por ver o seu talento publicamente reconhecido. Os dois se encontram quando Ismênia dos Santos, atriz e empresária do Teatro São Luís, solicita a Alencar uma peça para ser representada por José Dias Braga, jovem ator português radicado no Brasil. Sem nada de novo para lhes oferecer, Alencar tira da gaveta $O$ jesuíta, drama histórico de feição romântica composto muitos anos antes. As duas apresentações, ocorridas em 18 e 19 de setembro de 1875, foram um fracasso tão grande que a empresária se viu obrigada a tirar a peça de cartaz. Na imprensa da corte, as opiniões se dividiram: enquanto a maior parte dos comentaristas elogiou as qualidades d'O jesuíta, lamentando a ausência do público, alguns artigos, principalmente de pequenos jornais satíricos, aproveitaram a oportunidade para espicaçar o estridente deputado do partido conservador. ${ }^{4}$

Não obstante a acolhida favorável da imprensa, Alencar, ofendido pela indiferença do público e por algumas críticas feitas ao seu trabalho, publicou n'O Globo um conjunto de quatro artigos que visavam não apenas a defender e a explicar a peça, mas também a fustigar a sociedade carioca que, segundo ele, havia desertado da apresentação. No primeiro, estampado em 26 de setembro, afirmava que o episódio "foi ocasião de se exibirem teorias dramáticas, inteiramente avessas aos princípios da arte moderna" e alegava escrever com o intuito de rebater essas concepções equivocadas, que poderiam corromper ainda mais a literatura do país. ${ }^{5}$ O intróito magnânimo, contudo, não bastava para encobrir o despeito do autor, que acusava o público de ser estrangeirado e indiferente a tudo o que é nacional, chegando ao extremo de qualificar a sociedade da corte como "símia" (PAN, p. 24). Investigando os motivos do fracasso, considera que o fato de O jesuíta ter sido levado ao palco poucos dias depois do desenlace da questão religiosa teria atiçado a fúria dos liberais e dos maçons, parcela da sociedade que, iludida pelo título do drama, "voltou-lhe as costas com frio desdém" (PAN, p. 24). Mesmo que a mágoa do escritor ferido em seus brios seja perceptível ao longo dos quatro artigos, esse sentimento não o impede de desenvolver com clareza suas idéias sobre o drama histórico, gênero a que pertencia $O$ jesuíta. Explicando a

4. Para a história da representação de O jesuíta, ver as biografias de Alencar por Raimundo de Menezes, Magalhães Jr., Luís Viana Filho e Lira Neto. Para a análise da peça e das concepções teatrais de Alencar, ver Décio de Almeida Prado (1996), Flávio Aguiar e João Roberto Faria.

5. ALENCAR. O Teatro Brasileiro. A propósito do Jesuíta. In: COUTINHO. (Org.). A polêmica Alencar-Nabuco, p. 23. Daqui em diante citado como PAN. 
gênese da peça, escrita em 1861 para atender a uma encomenda de João Caetano, Alencar recorda o processo de composição, especialmente a dificuldade para encontrar o tema adequado, e discute aspectos técnicos importantes, como a construção dos personagens, os modos de exibição cênica e o problema da relação entre imaginação e história.

Em 3 de outubro de 1875, um dia antes da publicação do quarto artigo de Alencar, Joaquim Nabuco entra na liça para rebater seus argumentos. Já de saída, repudia a atitude do dramaturgo com relação ao público e afirma que ele "não tem [...] o direito de instaurar aos que não foram ouvir o Jesuíta, um processo de ausência" (PAN, p. 44). Nabuco aponta com clareza a contradição do escritor que, "diminuindo o seu público, [...] mutila-se a si [...]" (PAN, p. 45). Considerando que Alencar ainda não havia sido objeto de uma crítica isenta, propõe-se a analisar sua obra, abarcando os diversos gêneros que ela comporta, dos folhetins de Ao correr da pena ao conjunto dos romances, das cartas sobre A confederação dos tamoios às peças de teatro e aos escritos políticos de Erasmo. Ironicamente, Nabuco sugere que o autor de uma obra tão vasta e aparentemente diversificada, ainda não conhecia sua própria vocação: "A série de estudos que hoje começo sobre o Sr. J. de Alencar tem exatamente por fim descobrir a incógnita de sua vocação literária [...]" (PAN, p. 48). Esse artigo é o início do confronto entre os dois escritores, que até 21 de novembro irão escrever colunas semanais estampadas nas páginas de O Globo: Nabuco, "aos domingos"; Alencar, "às quintas". Como Nabuco tentou abarcar a obra completa de Alencar, as questões debatidas por eles cobrem um espectro muito amplo. Para tentar sistematizá-las, vou centrar esta exposição sobre dois gêneros, discutindo, num primeiro momento, as idéias dos polemistas sobre o teatro, e, a seguir, sobre o romance.

O principal ataque de Nabuco às peças de Alencar incidia sobre a exploração da temática escrava em $O$ demônio familiar e em Mãe, escolha que lhe parecia inadequada, pois fazia da escravidão o "característico" do teatro brasileiro (PAN, p. 48). Quanto a $O$ demônio familiar, considerava a figura de Pedro, o pequeno escravo responsável pela intriga, inverossímil e mal construída. Para Nabuco, o maior defeito da personagem residia na sua linguagem, que não apenas falseava a verdade, como feria as normas do teatro, não devendo, por isso, ser levada aos palcos: 
Essa linguagem de telegrama não é falada entre nós; mas se o fosse, ainda não teria o direito de passar da boca dos clowns, pintados de preto, dos nossos circos para a dos atores. [...] Já é bastante ouvir nas ruas a linguagem confusa, incorreta dos escravos; há certas máculas sociais que não se devem trazer ao teatro, como o nosso principal elemento cômico, para fazer rir. O homem do século XIX não pode deixar de sentir um profundo pesar, vendo que o teatro de um grande país, cuja civilização é proclamada pelo próprio dramaturgo escravagista [...] acha-se limitado por uma linha negra, e nacionalizado pela escravidão. Se isso ofende o estrangeiro, como não humilha o brasileiro! (PAN, p. 106)

Ao falar de Mãe, Nabuco afirma que o horror da situação da escrava herdada pelo próprio filho, que, posteriormente, se vê forçado a vendê-la, deveria ter impedido o dramaturgo de levá-la ao palco: "A arte nada tem que ver nesse mercado de carne humana, que o autor pôs em cena" (PAN, p. 111). Para ele, o tema escravo feria o decoro teatral, devendo, portanto, ser evitado: "Tudo o que há de triste, de raro, de extraordinário, de inverossímil nesse fato, devia impedir o Sr. J. de Alencar de explorá-lo e de carregar ainda de cores tão sombrias a escravidão, já de si tão triste" (PAN, p. 110-11). Além da inconveniência do tema, outro defeito da peça era o desrespeito à estrutura do gênero dramático: "No drama há uma ação que se desenvolve e de que sai o desenlace, uma cena para a qual convergem todos os efeitos; uma situação que o autor prepara, que o público espera. O drama é a luta, é o esforço, é a paixão, não é a desgraça nem a loucura" (PAN, p. 110). Citando Taine, Nabuco avalia que em Mãe o drama não se concretiza porque o suicídio da protagonista, que deveria ser o desenlace da ação, é um incidente que não decorre do seu desenvolvimento e, portanto, não se reveste do caráter de um acontecimento inevitável, adequado ao gênero, causando, pelo contrário, um efeito de surpresa no espectador. Comentando a censura à utilização do escravo no teatro alencariano, Roberto Schwarz destaca a contradição do abolicionista Nabuco, incomodado pela exploração teatral do escravo: "Nabuco põe o dedo em fraquezas reais, mas para escondê-las; Alencar pelo contrário incide tenazmente, guiado pelo senso da realidade, que o leva a sentir, precisamente aí, o assunto novo e o elemento brasileiro".

6. SCHWARZ. Ao vencedor as batatas, p. 32. 
Ao lado da questão do escravo como assunto literário, que ocupa o centro das suas considerações sobre o teatro alencariano, Nabuco aponta outros problemas que the parecem macular as peças do escritor cearense. Em O demônio familiar, critica a verborragia dos personagens, particularmente de Eduardo, que desempenha a função do raisonneur, comentando a ação e explicitando as teses defendidas pelo autor (PAN, p. 107). Também lhe parece inaceitável que todos se deixassem manipular por um pequeno escravo, como se fossem marionetes em suas mãos: "todos eles movem-se pelos arames que puxa um escravo, cujo sonho é ser cocheiro [...]. [...] nenhum desses indivíduos tem um caráter; quando tomam um ar sério, são ridículos, quando querem fazer rir entristecem" (PAN, p. 109). Apesar de Alencar orgulhar-se de ter suprimido o aparte da sua peça, Nabuco percebe claramente o seu uso em cenas como a do diálogo travado entre Pedro e Alfredo diante de Carlotinha, sem que a menina os escutasse (PAN, p. 108). Como o próprio Alencar fazia em "A Comédia Brasileira", Nabuco condena o recurso por ser estranho à naturalidade teatral. Quanto às Asas de um anjo, retoma as queixas sobre a imoralidade da peça feitas na época da sua encenação e proibição, em 1858, e a considera indigna de uma avaliação por parte da crítica, reputando-a, antes, um caso de polícia (PAN, p. 112).

Alencar inicia a defesa de suas peças que desenvolviam o tema da escravidão contestando a assertiva de que o assunto de uma obra fosse responsável pelo caráter da literatura de um país: "É o assunto dos dramas o que define uma literatura e a caracteriza, ou é, ao contrário, a escola desse drama, o que lhe imprime o cunho? Assim o característico do teatro de Sófocles, segundo o Sr. Nabuco, será o incesto" (PAN, p. 59). No folhetim número quatro, publicado em 28 de outubro de 1875, Alencar ressalta o aspecto inovador de $O$ demônio familiar e Mãe, que abordaram o problema da escravidão quando a voz dos "emancipadores" ainda não era ouvida no Brasil. Naquele contexto, seu objetivo era "patentear com o prestígio da cena os perigos e horrores dessa chaga social", trabalhando "em pró da grande causa da emancipação espontânea" (PAN, p. 120). Dessa perspectiva, o princípio moralizador do teatro seria aplicado à discussão do elemento servil, com o objetivo de sensibilizar a consciência dos proprietários e humanizar a relação entre senhores e escravos. No horizonte desse processo, a abolição surgia como ato da benevolência do proprietário e do progresso econômico do país. No primeiro

\section{ALENCAR. A comédia brasileira, p. 46.}


folhetim que redigiu em resposta a Nabuco, Alencar afirmara que "nem nos meus discursos, nem nos meus escritos aplaudi a escravidão; respeitando-a, como lei do país, manifestei-me sempre em favor de sua extinção espontânea e natural, que devia resultar da revolução dos costumes, por mim assinalada" (PAN, p. 58-9). Ao propor essa "extinção espontânea e natural", agia no interesse dos que pretendiam adiá-la indefinidamente. Antes da sua atuação contrária à lei do ventre livre, Alencar já havia se firmado como importante teórico da manutenção do sistema escravocrata no Brasil, cuja extinção the parecia uma ameaça ao Império. Segundo José Murilo de Carvalho, as Novas cartas de Erasmo, redigidas em 1867, num momento em que o sistema já era questionado por membros da elite política, representam a mais completa formulação do pensamento escravista elaborada no período posterior à independência: "Quando a defesa da instituição se limitava em geral ao argumento do pragmatismo, ele tentou justificá-la também em termos filosóficos e históricos". No campo teatral, Flávio Aguiar retoma a análise d'O demônio familiar feita por Décio de Almeida Prado e afirma que o dramaturgo pensava o problema da servidão de perspectiva conservadora, preocupado não com o escravo, mas com os males (não apenas relativos à segurança física, mas também de ordem moral) que ele podia acarretar para o senhor e sua família. ${ }^{10}$

O principal argumento de Alencar em defesa da utilização do tema escravo no teatro é a premissa de que a arte deveria lançar raízes no ambiente cultural, geográfico e humano em que florescia: "Que idéia faz este senhor de literatura, e sobretudo de literatura nacional? Acaso está ele convencido de que a arte e a poesia podem existir em um estado de completa abstração da sociedade em cujo seio se formam?" (PAN, p. 121). Lançando mão das idéias de Littré, propõe que "'as obras de arte [...] encerram primeiramente o que é do lugar e do tempo, depois, se elas são criação do gênio, uma parte que é destinada a todos os lugares e tempos" (PAN, p. 121). Os dois elementos apontados pelo crítico francês estariam presentes em $O$ demônio familiar e Mãe, "embora não sejam criação do gênio": "Encerram os costumes criados pela escravidão, elemento local e contemporâneo, e combinam esse elemento com as aspirações nobres da pureza da família e da regeneração da sociedade" (PAN, p. 122). Ao lado da necessidade de fixar a cor

8. ver ALENCAR. Cartas a favor da escravidão.

9. CARVAlHo. Escravidão e razão nacional. In: Pontos e bordados, p. 55.

10. AGUiAR. A comédia nacional no teatro de José de Alencar, p. 74. 
local, o que justifica a presença do escravo nas duas peças é a perspectiva moralizadora pela qual o problema é abordado: "Se a literatura é de todos os monumentos e arquivos humanos, o que melhor reflete a fisionomia de um povo e de uma idade: quem, a não ser o Sr. Nabuco, imputará como pecha e mácula, ao teatro de um país de escravidão o ter verberado esse vício político e socia?" (PAN, p. 122. Grifo meu).

Concebendo a comédia como um "daguerreótipo moral", afirma que a finalidade de $O$ demônio familiar era "mostrar os inconvenientes da domesticidade escrava" (PAN, p. 124). A opção de abordar o problema pelo seu lado mais inocente, colocando em cena um pequeno escravo, cujas intrigas não eram motivadas pela perversidade, mas pela travessura e pelo desejo de ser cocheiro, não dissiparia a nitidez da tese defendida: o escravo era uma ameaça à pureza da família e deveria ser afastado do seu convívio (PAN, p. 124). Quanto à linguagem falada por Pedro, Alencar a defende a partir de dois argumentos: primeiro, a sua fidelidade ao modelo observado (PAN, p. 122), e segundo, a sua validade como recurso de caracterização da personagem: "É sobretudo no teatro onde as figuras apresentam-se por si e não precedidas de descrições do autor, que elas devem falar, cada uma a linguagem peculiar, própria de sua profissão, de sua índole, de sua individualidade" (PAN, p. 123).

As censuras de Nabuco a Mãe incidiam sobre dois aspectos: a escolha de uma escrava para enaltecer o sentimento maternal e a inépcia do desfecho, que não lhe parecia decorrer dos sucessos que o precederam. A primeira crítica certamente desgostou o dramaturgo, que, numa página encharcada de sentimentalismo, havia dedicado a peça a sua própria mãe. ${ }^{12}$ Tanto na dedicatória do livro quanto na resposta a Nabuco, Alencar argumenta que, se escolheu uma mulher da mais baixa extração social como protagonista, foi para realçar, por contraste, a sublimidade da sua abnegação (PAN, p. 126). No tocante ao desfecho do drama, o suicídio de Joana é justificado como decorrência natural do seu caráter e da intriga, o que lhe conferia o estatuto de um acontecimento "fatal, indeclinável, produzido pela convergência da ação" (PAN, p. 125). No que dizia respeito a As asas de um anjo, como Nabuco apenas repetira as críticas feitas na época da proibição policial, Alencar retoma os mesmos argumentos que já havia utilizado

11. A expressão é empregada por Alencar em "A comédia brasileira", p. 45. 12. ALENCAR. Mãe, p. 293 
para defendê-la, ${ }^{13}$ reafirmando a validade da cena em que o pai de Carolina a assediava e insistindo no "intuito moral" da peça: "Não conheço na literatura antiga e moderna, uma obra em que o vício fosse mais implacavelmente flagelado do que nas Asas de um anjo" (PAN, p. 127).

Quanto ao romance alencariano, as críticas de Joaquim Nabuco retomam diversas questões que já haviam sido levantadas nas Cartas a Cincinato, de Franklin Távora, como a falta de observação da realidade e o abuso da imaginação, o uso de neologismos e a imitação de escritores estrangeiros, especialmente de Chateaubriand, Fenimore Cooper e Balzac. Diferentemente de Távora, que centrara suas críticas em O gaúcho e Iracema, Joaquim Nabuco procura recensear diversas obras, investigando, numa ordem aproximadamente cronológica, desde O guarani até Senhora.

Atacando um dos pontos centrais da estética alencariana, Nabuco questiona o caráter nacional da "falsa literatura tupi" de $O$ guarani, Iracema e Ubirajara (PAN, p. 84), e critica a ideia de que a fundação da literatura brasileira dependesse da exploração dos costumes selvagens:

Essa literatura indígena tem certa pretensão a tornar-se a literatura brasileira. Sem dúvida quem estuda os dialetos selvagens, a religião grosseira, os mitos confusos, os costumes rudes dos nossos indígenas, presta um serviço à ciência, e mesmo às artes. O que porém é impossível, é quererse fazer dos selvagens a raça, de cuja civilização a nossa literatura deve ser o monumento.

Nós somos brasileiros, não somos guaranis; a língua que falamos, é ainda a portuguesa. (PAN, p. 190)

Como se vê, o folhetinista refuta a linhagem romântica que pretendia utilizar o indígena como fonte de sugestões e imagens para a construção da literatura nacional. Segundo Roberto Ventura, a postura de Nabuco decorria do fato de ele conceber a arte como "expressão idealizada da sociedade branca e cosmopolita", o que,

13. Ver ALENCAR. As asas de um anjo. Advertência e Prólogo da 1. ${ }^{a}$ Edição, p. 924. 
consequentemente, o levou ao desejo de excluir o negro e o índio da sua representação literária. ${ }^{14}$ Da perspectiva do crítico, os "contos indígenas" de Alencar erravam não apenas ao identificar nos povos autóctones um dos elementos formadores da civilização brasileira, mas também na caracterização dos personagens (que não eram "verdadeiros selvagens" - PAN, p. 189) e na pintura da natureza: "A natureza americana ele estudou-a nos livros; [...] o escritor não conhece a linguagem que fala a natureza [...]. Quem lê os romances do Sr. J. de Alencar, vê que ele nunca saiu do seu gabinete e nunca deixou os óculos" (PAN, p. 209).

O problema da observação do espaço e dos tipos humanos representados por Alencar em seus romances já havia sido levantado por Franklin Távora na polêmica de 1871-72: "Sênio tem a pretensão de conhecer a natureza, os costumes dos povos [...] sem dar um só passo fora do seu gabinete. Isto o faz cair em freqüentes inexatidões, quer se proponha a reproduzir, quer a divagar na tela”. ${ }^{15}$ Retomando a ideia de que Alencar era um escritor de gabinete, Nabuco questiona a verossimilhança dos seus romances. Já no segundo folhetim, datado de 17 de outubro, afirma que "não poderia [...], sem escrever um livro tão grande como o Guarani, notar tudo o que nele parece-me ofender a história, a verdade, a arte, e as leis da composição literária [...]" (PAN, p. 86). Seguindo o exemplo de Franklin Távora, Nabuco parafraseia passagens do romance (a cena em que Peri luta com a onça ou o episódio em que bebe o curare para envenenar os inimigos no ritual de canibalismo, por exemplo) pontuando-as de comentários que visavam a ressaltar suas incongruências. Um exemplo dessa atitude pode ser visto na avaliação do episódio do curare: baseando-se na descrição que Humboldt faz da sua ação, Nabuco considera inexequível o episódio em que Peri ingere o veneno para exterminar os aimorés (PAN, p. 90). Como se vê, assim como ocorria nas Cartas a Cincinato, Nabuco compreende o verossímil primordialmente como fidelidade a um modelo extraliterário, passível de ser conhecido pela ciência, pela historiografia ou, simplesmente, pela observação objetiva da realidade.

O mesmo defeito de falta de observação apontado em $O$ guarani marcaria também as narrativas alencarianas de ambientação urbana. Numa avaliação que resume sua posição sobre elas, Nabuco considera Senhora como um romance em que

14. VENTURA. Estilo tropical, p. 44.

15. TÁvora. Cartas a Cincinato, p. 15. 
tudo, absolutamente tudo, é falso, contrário à realidade das cousas, pobre de fantasia, e em que parece-nos que o Rio de Janeiro é uma cidade de lunáticos. [...] não é a fantasia que é excessiva, não é a imaginação que é exuberante, é o senso moral que é nulo. [...] o Balzac brasileiro ver-seia em grandes dificuldades para dizer-nos em que parte da nossa sociedade achou um dos seus perfis fluminenses; Senhora tem a mesma cor local que o Gaúcho e Iracema; tudo está fora do seu verdadeiro meio, nada existiu (PAN, p. 184-85).

A par da deficiência da representação do ambiente social da corte, o que mais incomoda o crítico nessas narrativas é a construção das personagens, que lhe parecem incoerentes. Analisando Lucíola, não aceita a "dualidade" do caráter da protagonista, dividido entre "a virgem e a messalina" ( $P A N$, p. 135). O mesmo tipo de cisão se manifestaria em outros personagens, como Loredano, em O guarani, ou Emília, em Diva, nos quais a rápida mudança na linha de ação compromete a pintura:

O que é preciso é que uma dessas naturezas caprichosas seja coerente consigo mesma e que a diversidade dos seus atos, e dos seus sentimentos, as transições bruscas de seu coração, as contradições aparentemente inconciliáveis de sua vontade, a constante instabilidade de seu espírito, tudo seja referido de um modo ou de outro a um caráter sempre o mesmo" (PAN, p. 155-56).

Agora formulado em termos de coerência interna, o verossímil é concebido como a lógica que remete os atos do personagem a um "centro moral" capaz de explicar a multiplicidade de comportamentos aparentemente contraditórios, conferindolhes uma unidade que, da perspectiva de Nabuco, falta às "fisiologias" traçadas por Alencar e converte suas criações em monstros morais, como ocorre com Lúcia, Emília Duarte, Aurélia e Seixas.

Outro elemento importante da crítica de Nabuco aos romances de Alencar é que ele mantém-se fiel à idéia de que o gênero possuía finalidade moralizante. Ao analisar Lucíola, por exemplo, Nabuco faz um longo discurso a favor do casamento, instituição que lhe parecia ameaçada pelo exemplo da prostituta redimida ( $P A N$, p. 136-38). A defesa da idealização da natureza representada no romance, que deveria ser depurada de aspectos baixos, como a lascívia corruptora de Lucíola, aproxima-o novamente de Franklin Távora, que, 
apesar de proclamar o primado da observação da realidade em suas cartas, concebia a busca do ideal como finalidade maior do escritor. Para Joaquim Nabuco,

o romance tem menos influência do que o teatro, mas tanto no romance como no teatro o Sr. J. de Alencar perdeu de vista o ideal; por isso a sua influência em nossa literatura, se ele não vier a ter um sentimento diverso da missão do escritor, manifestar-se-á por uma poesia, artificial e exótica, emprestada a raças que não pensaram nem sentiram como a nossa, e, paralelamente, por um realismo sem elevação e sem verdade, para o qual a arte é a surpresa, a sensação e o escândalo (PAN, p. 139).

Defrontando-se novamente com questões havia muito levantadas pela crítica, Alencar retoma argumentos já desenvolvidos em outras ocasiões para responder a Joaquim Nabuco. Refuta que Chateaubriand tenha sido o fundador da poesia americana e, mais uma vez, nega que seus romances de tema indígena fossem uma imitação do mestre francês ou de Fenimore Cooper. Quanto à acusação de plágio, queixa-se que Nabuco fazia observações genéricas e exige que o crítico aponte as passagens onde haveria cópia.

Um dos aspectos mais interessantes das considerações desenvolvidas por Alencar ao responder aos ataques de Nabuco reside na defesa da verossimilhança de seus romances. Traçando um movimento perceptível em outros textos críticos, Alencar formula o problema a partir de duas ordens distintas de argumentos: na primeira, o verossímil é concebido de perspectiva referencial, na segunda, como efeito discursivo interno ao texto. A primeira atitude pode ser percebida quando procura assegurar a plausibilidade de personagens e episódios, alegando sua verdade histórica ou científica, sempre de modo a destacar sua fidelidade ao modelo extraliterário. Dessa maneira, para rebater a "censura de paracronismo" feita por Nabuco, que questionava a utilização de pistolas em $O$ guarani, apresenta um dado histórico que aponta o uso dessas armas em 1544 e cita uma tragédia redigida em 1603 na qual elas eram mencionadas (PAN, p. 94). Em outro momento da polêmica, quando Joaquim Nabuco lança mão do relato de Humbold para questionar a descrição do efeito do curare em $O$ guarani, Alencar, aceitando o debate no terreno científico, recorre à "autoridade do Dr. Sigaud", cujo parecer havia sido citado numa nota ao romance, para confirmar o efeito da droga, validando, então, a estratégia de Peri para envenenar os guerreiros aimorés que sitiavam a casa de Dom Antônio de Mariz (PAN, p. 144). Pautando-se pela mesma ordem de raciocínio, 
procura garantir a veracidade de personagens e episódios dos romances urbanos, defendendo sua fidelidade em relação aos modelos observados.

Em todos esses argumentos, o verossímil é formulado em termos referenciais e sustentado pela conformidade da narrativa com a realidade extratextual. A atitude de Nabuco e dos outros críticos que se orientavam pela idéia de observação (e mesmo a de Alencar, quando ingressa nesse tipo de disputa) faz lembrar a postura de Bouvard e Pécuchet, que, diante do romance histórico, exigiam a conformidade com a crônica e com a ciência, sendo que o segundo, a certa altura das suas leituras, "consultava a Biografia universal e empreendia a revisão de Dumas, do ponto de vista científico". ${ }^{16}$

Em Alencar, entretanto, a par desse tipo de raciocínio, encontra-se uma outra ordem de argumentos, na qual o problema da verossimilhança é formulado em termos de coerência interna. Assim, após defender a veracidade da descrição do efeito do curare com base na autoridade científica do Dr. Sigaud, sustenta sua validade em termos das necessidades de composição internas à narrativa:

É insensato o projeto? Não foram bem calculadas as probabilidades? Será burlada a esperança do selvagem? O drama não se ocupa com isto; apresenta o herói no relevo de seu caráter, no assomo de sua paixão. Sai-lhe, porém, ao encontro o crítico e fazendo gala de seus conhecimentos toxicológicos sobre o curare; trata de convencer a Peri que ele não deve sacrificar-se [...]. (PAN, p. 98)

Mais do que adequar-se à verdade científica, o episódio tem a finalidade de colocar diante dos olhos do leitor a coragem e a abnegação do herói do romance, disposto a todos os sacrifícios para salvar a sua senhora.

Em outra passagem, Alencar sustenta a verossimilhança de A pata da gazela não a partir de uma pretensa fidelidade ao modelo observado, mas com o argumento de que o romance é uma "fantasia", e portanto, livre dos constrangimentos da vida comum:

Não me ocuparei em defender o plano e a idéia da Pata da gazela. Este livro é uma fantasia, ou como o chamam os franceses, uma bluette. Tem esta espécie de escritos, ou devaneios literários, a mesma natureza dos arabescos na pintura e das variações em música.

16. FLAUBerT. Bouvard e Pécuchet, p. 118. 
Se deleitam o espírito, se nos causam uma impressão agradável e nos distraem por alguns momentos, preencheram seu fim [...]. (PAN, 198-99)

Pensado internamente como gênero, o romance transcende os limites do real, criando um universo pautado por regras próprias. Argumento semelhante havia sido apresentado em Como e porque sou romancista, pequena autobiografia intelectual redigida em 1873, mas publicada postumamente. Nesse texto, ao defender-se mais uma vez da acusação de imitar Fenimore Cooper, argumenta que, ao contrário do que ocorria com o escritor norte-americano, em O guarani o índio era pintado de perspectiva poético-idealizante, e não realista.

Perceptível em outros textos críticos de Alencar, esse movimento entre duas concepções de verossímil acabou fornecendo argumentos para críticos que, como Távora ou Nabuco, apontavam em suas narrativas a contradição entre a fantasia e o desejo de redigir "romances de costumes" representativos da vida nacional. Nas Cartas a Cincinato, Franklin Távora utilizou as notas e o argumento histórico de Iracema para, a partir de dados divergentes, arguir sua verossimilhança. Da perspectiva alencariana, contudo, não há contradição entre a base histórica e o exercício de imaginação, pois, como explicitou ao discutir a escolha do tema de $O$ jesuíta, o escritor deveria partir de um fato registrado pela primeira e, por meio da segunda, completar os aspectos deixados na obscuridade pelos cronistas e eleválos ao nível de grandiosidade conveniente ao gênero ( $P A N$, p. 29-31). A leitura do drama permite perceber a larga extensão na qual, para Alencar, o autor podia exercer sua atividade criadora: sobre o pano de fundo relativamente restrito de um acontecimento histórico definido (a expulsão da Companhia de Jesus) e com o concurso de alguns personagens históricos (o Conde de Bobadela, Basílio da Gama), o dramaturgo tece um vasto painel da nacionalidade para celebrar o dia da independência.

Além de questões concernentes ao teatro e ao romance, outros temas foram debatidos pelos dois polemistas, desde problemas literários relevantes até a miuçalha sem qualquer importância que sempre se levantava nesse tipo de debate, apenas com o intuito de "dar quinau" no oponente e afirmar a própria superioridade. No século XIX, a polêmica era um gênero prestigioso e uma forma socialmente 
reconhecida de um escritor projetar-se na arena pública, angariando o reconhecimento dos leitores. É esse, indubitavelmente, o principal intuito do jovem Nabuco ao investir contra a figura vetusta de Alencar, o que não passou despercebido ao experiente romancista:

Há dois meses um moço, desejoso de mostrar-se, apareceu na imprensa fazendo a crítica de minhas obras.

Dei-lhe uma prova de consideração, que outros escritores, mais modernos lhe recusaram, o que ele não me agradecerá. Respondi a seus artigos. (PAN, p. 219. Grifo meu.)

Alencar sabia bem do que estava falando, já que ele próprio utilizara a polêmica para conquistar notoriedade e desenvolveu, do início ao fim de sua vida pública, uma trajetória intelectual pontuada por confrontos: "A mim deleitam os certames literários", chegou a declarar, respondendo a uma crítica a Sonhos d'ouro. ${ }^{17}$ Polemista incansável, debateu os principais temas em pauta no seu tempo, abarcando questões políticas e jurídicas. No terreno literário, das cartas sobre $A$ confederação dos tamoios (1856) até o embate com Joaquim Nabuco (1875), envolveu-se em inúmeras disputas, como a controvérsia a propósito da censura de As asas de um anjo, as discussões decorrentes de críticas a aspectos gramaticais de suas obras ou o debate das Questões do dia, com José Feliciano de Castilho e Franklin Távora. Nessas polêmicas, ora os contendores utilizaram a forma epistolar, criando personagens como Ig, Semprônio e Cincinato, que assinavam as cartas; ora adotaram a forma do artigo crítico, subscrito por pseudônimos ou pelo próprio nome, como no caso da polêmica com Nabuco. Segundo Magalhães Jr., esse último debate chamou a atenção dos contemporâneos pela peculiaridade de se desenrolar nas páginas de um único jornal, que abrigou os dois oponentes:

Nunca o meio literário brasileiro tivera espetáculo tão sensacional como o que deram Joaquim Nabuco e José de Alencar ao se engalfinharem pelas colunas de $O$ Globo. Em geral, as polêmicas dessa espécie eram travadas com cada contendor barricado num jornal diferente. Mas, dessa vez, a briga era dentro da mesma trincheira, um dos brigões escrevendo aos domingos e o outro às quintas-feiras. ${ }^{18}$

17. ALENCAR. Os Sonhos d'ouro, p. 128.

18. magalhães Jr. José de Alencar e sua época, p. 355. 
A polêmica se estendeu até o dia 21 de novembro de 1875, quando, no seu sétimo folhetim, Nabuco enveredou pelo terreno da política. A partir daí, sem dar qualquer explicação aos leitores, Alencar retirou-se da arena. Numa nota manuscrita, que não chegou a ser publicada na época, mas integra a edição preparada por Afrânio Coutinho a partir de recortes colecionados pelo romancista, Alencar explica que depois de ter debatido os grandes temas nacionais com os principais políticos da época não poderia perder seu tempo com um "filhote": "A política estou habituado a discuti-la com seu pai" (PAN, p. 219).

Alencar morreu dois anos depois do confronto com Nabuco, mas ainda teve tempo de publicar dois romances ( $O$ sertanejo, em 1875, ao qual ele chega a se referir durante o debate, e Encarnação, que apareceu no folhetim do Diário Popular em 1877) e de deixar uma série de projetos inacabados. Morreu amargurado, perseguido pela ideia de que sua obra e seu nome seriam esquecidos pela posteridade. Nabuco, por seu turno, se não conseguiu se firmar como poeta ou romancista, notabilizou-se na luta pelo abolicionismo e logrou realizar suas veleidades de escritor, não no campo das belles lettres, mas no gênero histórico, no qual deixou uma das mais sólidas e importantes obras do século XIX, com destaque para Um estadista do império. Anos depois, arrependeu-se do tom desabrido com que, quando jovem, tratou o velho Alencar. Numa passagem de Minha formação (1900) sempre citada pelos estudiosos da polêmica, ao falar das suas atividades depois do regresso da primeira viagem à Europa, expressa esse sentimento com clareza:

fui colaborador literário do Globo e travei com José de Alencar uma polêmica, em que receio ter tratado com a presunção e a injustiça da mocidade o grande escritor (digo receio, porque não tornei a ler aqueles folhetins e não me recordo até onde foi a minha crítica, se ela ofendeu o que há profundo, nacional, em Alencar: o seu brasileirismo). ${ }^{19}$

Menos conhecidas, mas orientadas no mesmo sentido de rever a atitude assumida quando jovem, são duas cartas pessoais, escritas em 1905, nas quais Nabuco justificava seu voto a favor de Mário de Alencar na eleição para a Academia Brasileira de Letras. Na primeira, destinada a Carlos Magalhães de Azeredo, dizia: "Pago assim a minha dívida, ou antes expio a minha falta para com o pai”. Na segunda,

19. NABUCO. Minha formação, p. 74 . 
respondendo à indagação de Oliveira Lima, explica sua atitude: "Votei pela dívida em que estava com o pai, José de Alencar, por o ter atacado, quando jovem, com tanta falta de veneração nacional". ${ }^{20}$ Além da retratação, a passagem autobiográfica e o testemunho a Oliveira Lima importam por mitigar a oposição local/cosmopolita, tão acentuada na polêmica e na sua recepção: ao final, o que o estrangeirado Nabuco reconhece de positivo na obra do nacionalista Alencar é justamente o seu "brasileirismo".

\section{Nabuco and Alencar}

Abstract: This paper aims at analysing the notorius polemics among José de Alencar and Joaquim Nabuco, which took place in the Brazilian newspaper "O Globo", from September to November 1875, specially focusing on the concepts of novel and play - as literary genres - developed by those authors. Keywords: Novel, Play, Literary Polemics.

$$
\text { Referências }
$$

AGUIAR, Flávio. A comédia nacional no teatro de José de Alencar. São Paulo: Ática, 1984

ALENCAR, José de. A comédia brasileira. In: Obra completa. V. 4. Rio de Janeiro: Aguilar, 1960.

ALENCAR, José de. As asas de um anjo. Advertência e Prólogo da 1. Edição. In: Obra completa. V. 4. Rio de Janeiro: Aguilar, 1960.

ALENCAR, José de. Cartas a favor da escravidão. São Paulo: Hedra, 2008.

ALENCAR, José de. Mãe. In: Obra completa. V. 4. Rio de Janeiro: Aguilar, 1960.

ALENCAR, José de. O gaúcho. O tronco do ipê. Rio de Janeiro: José Olympio, 1977 .

ALENCAR, José de. Os sonhos d'ouro. In: COUTINHO, A. Caminhos do pensamento crítico. Rio de Janeiro: Americana, 1974.

ALONSO, Angela. Joaquim Nabuco. São Paulo: Cia. das Letras, 2007.

BROCA, Brito. Românticos, pré-românticos, ultra-românticos. São Paulo: Polis, 1979.

20. Apud VIana filho. A vida de José de Alencar, p. 269. 
CARVAlHO, José Murilo de. Escravidão e razão nacional. In: Pontos e bordados. Belo Horizonte: UFMG, 1999.

COUTINHO, Afrânio. (Org.). A polêmica Alencar-Nabuco. Rio de Janeiro: Tempo Brasileiro, 1978.

FARIA, João Roberto. José de Alencar e o teatro. São Paulo: Perspectiva, 1987.

FLAUBERT, Gustave. Bouvard e Pécuchet. Rio de Janeiro: Nova Fronteira, 1981.

MAGALHÃES Jr. Raimundo. José de Alencar e sua época. Rio de Janeiro: Civilização Brasileira, 1977.

MENEZES. Raimundo de. José de Alencar. Literato e político. Rio de Janeiro: Livros Técnicos e Científicos, 1977.

NABUCO, Joaquim. Minha formação. São Paulo: Cia. Ed. Nacional, Rio de Janeiro: Civilização Brasileira, 1934.

NETO, Lira. O inimigo do rei. São Paulo: Globo, 2006.

PRADO, Décio de Almeida. O drama romântico brasileiro. São Paulo: Perspectiva, 1996.

PRADO, Décio de Almeida. Os demônios familiares de Alencar. In: Teatro de Anchieta a Alencar: São Paulo: Perspectiva, 1993.

SCHWARZ, Roberto. Ao vencedor as batatas. São Paulo: Livraria Duas Cidades, 1988.

TÁVORA, Franklin. Cartas a Cincinato. Estudos críticos de Semprônio. Pernambuco: J. W. Medeiros, 1872.

VENTURA, Roberto. Estilo tropical. São Paulo: Cia. das Letras, 1991.

VIANA FILHO, Luís. A vida de José de Alencar. Rio de Janeiro: José Olympio, 1979. 